\title{
The Early Childhood Safety Education (A Case Study at Kindergartens in Banjar)
}

\author{
Devita Savitri1, ${ }^{1,}$, Badru Zaman ${ }^{2}$ \\ ${ }^{1,2}$ Departement of Early Childhood Education, School of Postgraduate, Universitas Pendidikan Indonesia \\ *Corresponding author. Email: devita@upi.edu
}

\begin{abstract}
The background of this study is the frequent occurrence of early childhood accidents. Children as objects of protection need to be equipped with knowledge and attitudes and behaviours related to their safety. One way to avoid early childhood hazards is to increase their understanding of hazards and ways to overcome hazards through self-safety education. This study aims to describe the implementation of early childhood independent education and to find out the results of an assessment of Kindergartens in Banjar. This research is a case study with a qualitative exploratory approach. This research was conducted from July to September 2020 involving 63 children. The results showed that the method of self-safety education at Kindergartens in Banjar was the Kindergarten Watching method. This method is the result of the development of the Town Watching. The stages include Field survey, develop a map of observation, Discussion to solve the problem, and Presentation. Children can attend the process of self-safety education. However, there were still $18.60 \%$ of new children began to develop in telling the results of the description related to potential hazards. Selfsafety education at Kindergartens in Banjar can improve children's understanding of hazards and how to avoid them.
\end{abstract}

Keywords: Self-safety, early childhood, hazards.

\section{INTRODUCTION}

Child protection is one of the services that must be provided for in PAUD institutions. The success of early childhood protection services can be seen from the fulfilment of three components, namely the provision of a safe, comfortable and pleasant environment, mastery of knowledge about child protection, and having attitudes and behaviours that are in accordance with child protection [1]. Mastery of knowledge, attitudes and behaviours regarding protection must be owned by all stakeholders in PAUD institutions, namely children, teachers, managers, and other education personnel.

According to Vinje [2], children are classified as prone to accidents because they have cognitive limitations. Limited understanding of children causes children to be less able to anticipate and overcome dangerous conditions that arise. This can be fatal for his safety. Data on the incidence of accidents in children at school shows $34 \%$ of deaths are caused by motorized vehicles, $5 \%$ by falls, $4 \%$ by fire, $13 \%$ by drowning, and $21 \%$ by accidental injuries [3]. According to the results of basic health research conducted by Balitbangbankes Kemenkes RI [4], the most common causes of injuries were falls (40.9\%) and motorcycle accidents (40.6\%), furthermore, the causes of injury were due to sharp/blunt objects $(7,3 \%)$, other land transportation $(7.1 \%)$ and a fall $(2.5 \%)$, while for causes that have not been mentioned the proportion is very small. The prevalence of injuries caused by falls was $91.3 \%$ (age $<1$ year), $79.4 \%$ (age 1-4 years), and 57.3\% (age 5-14 years).

Child accidents at play areas in PAUD institutions are very likely to occur. Accidents that often occur are injuries or injuries from falls. The cause of many children's injuries is due to the child's impatience in playing and queuing so that the child is less aware of the dangers around him. Norton in Kuschithawati [5] states that $34 \%$ of household injuries in rural areas occur in children aged 0-5 years and 28\% are aged 6-20 years, while for urban areas $26 \%$ of injuries occur in children 0 5 years. And 29\% for children 6-20 years. Most of the injuries occurred while the child was playing. Therefore, children need to get an understanding of the conditions in the playground where it is possible that the selected game is unsafe so they are prone to having accidents while playing [6]. This is part of an effort to teach self-safety to children.

Children as objects of protection need to be equipped with knowledge and attitudes and behaviours related to their own safety. One way to make children safe from harm is to increase their understanding of dangers and ways of dealing with hazards through self-safety 
education [6]. Sumargi et al [7] conducted preliminary research on self-safety against dangerous situations that are close to children, namely the danger of fire, the danger of unknown people, the danger of accidents at the game venue, the danger of thuggery in the school environment and the danger of accidents on the highway. Early childhood is at the preoperational stage, one of which is characterized by an inability to use other people's points of view and a tendency to consider things only from their own point of view (egocentrism). Therefore, in play, early childhood relies more on their own interpretation of what is considered danger and safety. Children often fail to perceive something well, even many children do not understand the concept of danger and harmlessness [6]. Often this interpretation differs from the adult point of view. For this reason, it is necessary to provide correct information about hazards and safety through self-safety education.

Safety education is more aimed at shaping attitudes and behaviours, in order to apply useful rules for maintaining one's own safety and the safety of others [8]. The target of coaching in safety education is the child's attitude and ability to make the right decisions, supported by the skills to take action. In order for someone to be safe, avoid accidents, Yost in Muchtamadji [8] recommends four main principles that must be adhered to, namely (1) recognizing danger, (2) avoiding danger, (3) controlling unavoidable dangers, and (4) not creating danger. This principle is in nature and applies generally to various areas of life, such as transportation, recreation and sports.

There are problems related to the self-safety of early childhood, namely (1) it is very possible for children to have accidents at play places in PAUD institutions; (2) children as objects of protection are not equipped with knowledge and attitudes and behaviours related to their own safety; and (3) the integration of self-safety education in early childhood learning needs to be adjusted to the characteristics of the child and the direct involvement of children. Facing these problems, it is necessary to have an overview of early childhood safety education that has been carried out in an early childhood education institution, which includes the process of implementing early childhood safety education and the results of this education. This description can be a reference for PAUD educators in implementing early childhood safety education in their institutions and can increase children's understanding of self-safety so that children's accidents in institutions can be minimized.

\section{METHOD}

This research is a case study research with a qualitative descriptive exploratory approach. Researchers want to reveal and interpret the meanings of the facts that are related to early childhood safety education. Case study research has determined the research subject in advance, so it does not have to select the population and sample. The research subject in the case study is the case itself [9]. The research activity was carried out from July to September 2020 at Kindergartens in Banjar and involved 63 children.

The data collection techniques used were observation, interviews, and document analysis. Observations were made from the beginning of the study until the end of data collection on early childhood selfsafety education. Interviews were conducted to obtain information directly from educators about the implementation of self-safety education and changes in children's attitudes and behaviours regarding self-safety. Document analysis is used to complement the data obtained from observations and interviews. The data analysis technique was carried out by using qualitative analysis. Qualitative analysis uses interactive analysis developed by Miles \& Huberman. This analysis consists of three components, namely data reduction, data presentation, and drawing conclusions. Data reduction includes the selection process, focusing on simplifying the data arising from field records. Data presentation is displayed in the form of narrative text which is systematically arranged to facilitate the data analysis process. Data analysis used an interactive model, meaning that data reduction and presentation were carried out by paying attention to the results of the data collected. Conclusions drawn based on the results of data and information analysis.

\section{RESULT AND DISCUSSION}

The implementation of the PAUD program is an integration of education, care, protection, health and nutrition services. The success of early childhood protection services in institutions can be seen from the fulfilment of three components, namely the provision of a safe, comfortable and pleasant environment, mastery of knowledge about child protection, and having attitudes and behaviours that are in accordance with child protection. Early childhood self-safety education at Kindergartens in Banjar is carried out through activities that are integrated with daily learning. The method used in self safety education is the Kindergarten Watching method. The Kindergarten Watching method is the result of a model development that has been carried out by BP PAUD \& Dikmas East Kalimantan in 2017. Kindergarten Watching method is an adoption and modification of Town Watching developed by Professor Yujiro Ogawa from Fuji-Tokoha University. Ogawa [10] states that Town Watching has four stages, namely (1) step 0: learn about disasters; (2) know our town / field survey; (3) develop a map; (4) conduct group discussions and make presentations. Town Watching has been used for disaster prevention education in schools. The General Insurance Association of Japan (GIAJ) and the Nippon Volunteer Network Active in Disaster (NVNAD) have 
designed this method for elementary school children and as a result, children can enjoy disaster prevention learning in their daily lives. Town Watching has also been adopted by Amelia [11]. The study concluded that there is an influence between Kindergarten Watching and stimulation of visual spatial and kinaesthetic intelligence in children. Sari \& Khatimah [12] also performed another adoption. This study concluded that the preparedness attitude of students at MIN Blang Mancung increased with the application of the School Watching method.

This method is developed and adapted to the characteristics of early childhood and meets early childhood learning methods, scientific approaches and principles of PAUD learning. In the guidelines for implementing the 2013 PAUD Curriculum, it is mentioned how early childhood learning, namely (1) children learn gradually, (2) children's thinking is unique, (3) children learn in various ways, and (4) children learn when socializing, whereas the principles of PAUD learning are (1) learning through play, (2) child development-oriented, (3) child-oriented overall, (4) child-centred, (5) active learning, (6) character development oriented , (7) oriented to the development of life skills, (8) a conducive environment, (9) oriented to democratic learning, and (10) using various media and learning resources. A fun method of self-safety education is needed, according to research by Bolig, Wahl, \& Svendsen [13], that it is important that self-safety education is provided in schools as a preventive effort in overcoming the reduction in the prevalence of child injury rates in schools. Teens begin their transition period by trying new things so they won't be perceived as children. Prevention of dangerous conditions needs to be done, such as providing training on first aid and introducing interesting media containing self-safety materials. Children are introduced to their own safety through fun play activities. In addition, children are also involved directly and actively in it.

Children are given the opportunity to participate to identify their school environment, find places that have the potential to harm themselves and know how to avoid them. Early childhood safety education at Kindergartens in Banjar consists of four stages, namely (1) learning about hazards; (2) field survey; (3) hazard map; and (4) how to avoid hazards. Danger is defined as an object, place or behaviour that can cause harm, this definition refers to OHSAS [14] that danger is any condition that can be detrimental to injury or other loss, or danger is a source, situation or action that has the potential to injure humans or illness. Or a combination thereof.

The modification of the Kindergarten Watching method from the previous method is first, this method is used for reducing the risk of hazards in the playground. Second, stage 2 (survey) uses drawing and storytelling techniques. Drawing is an activity that is closely related to early childhood. Effendi [15] states that drawing activities for early childhood should be interpreted to form and develop a child's personality so that their logical and emotional abilities develop in a balanced manner. In drawing, children express the ideas they see and then express them in strokes before they can express them in words, and children can express their expressions and imagination without limits. Third, stages 3 (hazard map) and 4 (how to avoid hazards) are carried out simultaneously. Each child finds a hazard map, proceeding directly to stage 4 . And so on, if another child finds a hazard map, continue to discuss how to avoid danger. This is to keep the child's attention momentum from being lost. According to Judarwanto in Istiqomah [16], the average attention span is at 2 years old for 7 minutes, 3 years old for 9 minutes, 4 years old for 12 minutes, 5 years old for 14 minutes.

Before the activity is carried out, the educator prepares a lesson plan. In the plan, the core competencies and basic competencies that are to be achieved in early childhood self-safety education are stated. Furthermore, educators make a simple and easy-to-understand plan for the institution. Educators also prepare tools and materials needed in activities, namely stationery and paper. Then the educator runs step by step in early childhood selfsafety education.

The first stage is the hazard learning stage. The steps taken by the educator are (1) conveying information about possible dangers and consequences if an accident occurs. This information can be conveyed by telling stories, storytelling, reading books, showing videos or other ways that are tailored to the characteristics of the child, and (2) explaining the purpose of the activities to be carried out. It is very important for children to know the definition and understanding of hazards. Research by Sumargi et al [6] shows that children's understanding is relatively good in the majority of hazards, but most of the research subjects admit that they know themselves about matters related to self-safety, no one teaches this issue.

The second stage is the field survey. The field survey stage includes (1) the educator explains the rules of the game in the survey; (2) educators divide groups according to the needs and extent of the PAUD institution environment; (3) educators invite children to walk to see the PAUD institution environment; and (4) educators ask children to draw environments that have potential hazards. This survey activity is intended so that children can get to know their institutional environment and identify potential hazards. This recognition and identification are very necessary because school environmental factors are important to pay attention to in efforts to self-safety and schools are said to be safe, it can be seen from the density of students in the classroom, adequate lighting, and school grounds [5]

The third stage is the hazard map stage. Before the hazard map stage begins, educators put up a plan of the institution in the classroom. The steps in the hazard map 
stage are (1) the educator explains the rules of the game in the hazard map stage; (2) the educator asks the child to stick the results of the picture on the institutional plan; and (3) the educator asks the child to tell the results of the picture.

The fourth stage is the stage of how to avoid danger. This stage includes the following steps (1) the child tells the results of the description, (2) the educator guides the discussion on how to avoid the dangers associated with the results of the child's description, and (3) the educator and the child draw conclusions. The third and fourth stages are the hazard map stage and how to avoid hazards. These two stages are carried out simultaneously, meaning that a child who has completed the hazard map stage is immediately proceeded to the stage of how to avoid danger. The educator will direct and guide these stages until all children in turn can follow the process.

The implementation of early childhood safety education at Kindergartens in Banjar actively involves children. Children are strived to always participate in every stage. Observations of children's activities are outlined in a measurement scale adjusted to the 2013 PAUD Curriculum, namely (1) BB (Belum Berkembang), children do must be guided or exemplified by educators; (2) MB (Mulai Berkembang), children do still need to be reminded or assisted by educators; (3) BSH (Berkembang Sesuai Harapan), children can do it independently and consistently without having to be reminded or exemplified by educators; and (4) BSB (Berkembang Sangat Baik), children can do it independently and can help their friends who are not able to.

\section{CONCLUSION}

The conclusion that can be drawn in this research is that early childhood self-safety education at Kindergartens in Banjar is implemented by fulfilling the methods and principles of early childhood learning. This self-safety education is one of the preventive efforts to reduce accidents in institutions. The goal is to provide understanding to early childhood about dangers and how to avoid them. In doing so, children are given the opportunity to participate in identifying their play environment, finding objects/places/behaviours that have the potential to harm them. Children are also actively involved in activities to avoid these dangers.

\section{ACKNOWLEDGMENTS}

Thank you to the principal, teacher, parents, and all parties, who has helped carry out the research and writing of this article. Don't forget to say Thanks also to the editors and reviewers of the Atlantis Journal who have provided opportunity for the author so that the article can be published.

\section{REFERENCES}

[1] Direktorat Pembinaan PAUD Dirjen PAUD \& Dikmas. Petunjuk teknis penyelenggaraan PAUD holistik integratif di satuan PAUD. Jakarta: Kemdikbud; 2015.

[2] Vinje MP. Children as pedestrian: Abilities and limitations. Accident, Analysis and Prevention. 1991;13(3):225-240. DOI: https://doi. org/10.1016/ 0001-4575(81)90006-3.

[3] Nugratmaja AS. Penatalaksanaan pencegahan kecelakaan anak usia pra sekolah di Dusun Geblagan Kecamatan Kasihan Kabupaten Bantul, Yogyakarta: Universitas Muhammadiyah Yogyakarta; 2011.

[4] Badan Penelitian dan Pengembangan Kesehatan. Riset kesehatan dasar. Jakarta: Kementerian Kesehatan RI; 2013. Available from: http://www. depkes.go.id/resources/download/general/Hasil\% 20Riskesdas\% 202013.pdf A.M.

[5] Kuschithawati R, Magetsari R. Faktor risiko terjadinya cedera pada anak usia sekolah dasar. Berita Kedokteran Masyarakat. 2007;23(3):131-141. DOI: https://doi. org/10.22146/bkm.3620.

[6] Sumargi AM, Kurniawan Y, Sasongko JW, Simanjuntak E. Apa yang diketahui anak-anak sekolah dasar tentang keselamatan dirinya: Studi pendahuluan tentang pemahaman akan keselamatan diri. INSAN Media Psikologi. 2005;7(3):226-249.

[7] Sumargi AM, Simanjuntak E. Pemahaman dan sikap orang tua pada keselamatan diri anak-anak usia dini. Temu Ilmiah Nasional IPPI, IPS \& Fakultas Psikologi UNAIR; 2010.

[8] Muchtamadji A. Konsep dan penerapan pendidikan keselamatan, Jakarta: Direktorat Jenderal Olahraga; 2004.

[9] Arikunto S. Manajemen Penelitian. Jakarta: Rineka Cipta; 1995.

[10] Ogawa Y. Town watching for disaster reduction for effective and successful risk communication. In United Nations World Conference on Disaster Reduction Kobe; 2010. Available from: nuruddinm .files.wordpress.com/2013/08/ohsas-18001-2007dual-language.pdf.

[11] Amelia L. Metode kindergarten watching siaga bencana gempa bumi terhadap stimulasi kecerdasan visual spasial dan kecerdasan kinestetik anak usia dini di TK Syeikh Abdurrauf Blang Oi Banda Aceh. Jurnal Tematik. 2012;5(2):165-179. DOI: https://doi .org/10.24114/jt.v5i02.3207.

[12] Sari SA. The application of school watching methods to increase the earthquake disaster preparedness of primary school students MIN Blang Mancung, Aceh. Journal of Education and Learning. 
2015;9(3):241-245. Available from: http://dx.doi. or g/10.11591/edulearn.v9i3.2301.

[13]Bolig G. Wahl HA, Svendsen MV. Primary school children are able to perform basic life-saving first aid measures. Journal of Resuscitation. 2009;80:689692.

[14]OHSAS. Sistem manajemen keselamatan dan kesehatan kerja-persyaratan [Internet]. Jakarta; 2007. Available from: https://nuruddinmh.files. wordpress.com/2013/08/ohsas-18001-2007-duallanguage.pdf.

[15]Effendi A. Kegiatan menggambar pada anak usia dini [Internet]; 2016 [cited 2020 Nov 5]. Available from: http://paudunia. blogspot.co.id.

[16] Istiqomah A. Upaya meningkatkan perhatian anak melalui metode bercerita dengan media boneka tangan pada anak kelompok A TK ABA Jogoyudan Yogyakarta. Pendidikan Guru PAUD S-1. 2015;4(7):1-8. Available from: http://journal.stude nt.uny.ac.id/ojs/index.php/pgpaud/article/view/365

A. 